\title{
Two High Performance Liquid Chromatographic Methods for the Determination of $\alpha$-Tocopherol in Serum Compared to Isotope Dilution-Gas Chromatography-Mass Spectrometry
}

\author{
Ruediger Kock, Sabine Seitz, Bert Delvoux and Helmut Greiling
}

Institut für Klinische Chemie und Pathobiochemie, Medizinische Fakultät der RWTH Aachen, Universitätsklinikum der RWTH Aachen, Aachen, Germany

Summary: Two high performance liquid chromatographic methods (HPLC) with isocratic reversed-phase separation are presented for the determination of $\alpha$-tocopherol (vitamin E) in serum. In the first method $\alpha$-tocopherol acetate is used as internal standard, detection of absorbance is performed at $284 \mathrm{~nm}$. In the second method tocol is used as internal standard, detection of fluorescence is performed with an excitation wavelength of $292 \mathrm{~nm}$ and emission wavelength of $325 \mathrm{~nm}$. Both methods require a liquid-liquid extraction as sample preparation.

The results of both HPLC methods have been tested by method comparison for $\mathrm{n}=25$ serum samples versus an isotope dilution-gas chromatography-mass spectrometry (ID-GC-MS) method using $\alpha$-tocopherol- $\mathrm{d}_{6}$ as internal standard.

The imprecision within-run was lower than $2.5 \%$ for the UV method and lower than $1 \%$ for the fluorescence method for both standards and serum pools. The between-run imprecision, obtained for serum pools, was below $5 \%$ for the UV method and not higher than $1.5 \%$ for the fluorescence method and not higher $1.8 \%$ for the ID-GCMS. Recovery experiments performed by spiking pool sera with $\alpha$-tocopherol showed recoveries between $98.5 \%$ and $100.6 \%$ for all methods studied. The result of the method comparison was a coefficient of correlation of $r=0.998$ for the HPLC method with fluorescence detection to the ID-GC-MS reference method and a coefficient of correlation of $r=0.981$ for the HPLC method with UV detection to the ID-GC-MS reference method.

Both methods presented are useful for the analysis of $\alpha$-tocopherol in patient samples. If detection of fluorescence is used, imprecision and inaccuracy of the HPLC method are comparable to the ID-GC-MS chosen as reference method.

\section{Introduction}

Vitamin $\mathrm{E}$ is a water-insoluble vitamin, representing a group of natural products, the tocols and tocotrienols, the principal metabolite is a $\alpha$-tocopherol $(5,7,8$-trimethyl-tocol). Due to their chemical structure, tocols as well as tocotrienols are highly reactive scavengers for oxygen-derived radicals $(1,2)$ and a deficiency may lead to neuropathologic and myopathologic alterations, mainly as a result of radical-induced membrane deterioration. Inadequate resorption in the course of cystic fibrosis or congenital disfiguration of the hepatobiliary system quickly causes a deficiency of vitamin $\mathrm{E}(1,3)$.

In this study we present two HPLC methods for the determination of $\alpha$-tocopherol in serum. The methods are based on reversed-phase separation and the detection of fluorescence or absorbance. This is the first study where the inaccuracies of the presented HPLC methods for the determination of $\alpha$-tocopherol are evaluated by comparison to isotope dilution-gas chromatography-mass spectrometry using $\alpha$-tocopherol- $\mathrm{d}_{6}$ as internal standard.

\section{Materials and Methods}

Chemicals

The $D, L$ - $\alpha$-tocopherol and the $D, L$ - $\alpha$-tocopherol acetate were obtained from Sigma (Deisenhofen, Germany), the tocol was kindly provided by Hoffmann-LaRoche (Basel, Switzerland), the $\alpha$-tocopherol- $\mathrm{d}_{6}$ used as internal standard was kindly provided by $\mathrm{Mr}$. Graham Burton, Steacie Institute for Molecular Sciences, National Research Council of Canada (Ottawa, Ontario, Canada). TriSil ZReagent (trimethylsilylimidazole/pyridine) was obtained from Pierce (Oud-Beijerland, Netherlands), pyridine as silylation-grade solvent was from Macherey \& Nagel (Düren, Germany). The pyridine used as solvent for the silylation was dried using molecular sieve from Sigma (Deisenhofen, Germany). Methanol, acetonitrile and hexane were obtained as HPLC-grade solvents from J. T. Baker (Groß-Gerau, Germany). All other chemicals had a least p.a. quality and were obtained from Merck. The $\mathrm{C}_{18}$-cartridges used for solid-phase extraction in the course of the sample preparation for the ID-GC-MS measurements were Sep-Pak Vac Cartridges with $3 \mathrm{ml}$ volume from Waters (Eschborn, Germany) that were conditioned with $3 \mathrm{ml}$ methanol and $3 \mathrm{ml}$ bidemin. water before use.

For the imprecision and recovery experiments 5 pools were prepared from patient sera. The serum pools used were obtained by mixing blood samples of healthy donors and spiked with different amounts of $\alpha$-tocopherol to achieve concentrations between 2.5 $\mathrm{mg} / \mathrm{l}$ and $25 \mathrm{mg} / \mathrm{l}$. For the method comparison, 25 serum samples 
from hospitalized patients were used. All blood specimens were collected in Sarstedt-Monovettes with separation gel.

\section{Instruments and settings}

\section{High performance liquid chromatography}

The HPLC was performed on an HPLC system consisting of a Waters 600E pump, an autosampler Waters 717, a 4-wavelengthUV-/Vis-absorbance-detector Waters 490E set to $284 \mathrm{~nm}$ and 292 $\mathrm{nm}$ and ratio 284/292, a tunable fluorescence detector Shimadzu RF-551 set to an excitation wavelength of $292 \mathrm{~nm}$ and an emission wavelength of $325 \mathrm{~nm}$ and for system controlling, data acquisition and peak integration a Maxima 825 chromatography manager was used.

For both HPLC methods, the combination of a Nucleosil 100-5C18 (5 $\mu \mathrm{m}$ particle size), $250 \mathrm{~mm} \times 4.0 \mathrm{~mm}$ analytical column (Chromatographie-Service, Eschweiler, Germany) and a Lichrosorb RP-18-5 guard column (Chromatographie-Service, Eschweiler, Germany) was used.

For the HPLC method with UV detection, an isocratic eluent with $65 \%$ acetonitrile, $34 \%$ methanol and $1 \%$ bidemin. water at a flow rate of $2.0 \mathrm{ml} / \mathrm{min}$ was used.

For the HPLC method with fluorescence detection, methanol at a flow rate of $1.5 \mathrm{ml} / \mathrm{min}$ was used as eluent

\section{Isotope dilution-gas chromatography-mass spectrometry}

The instrument used was a Finnigan 1020 gas chromatograph quadrupole mass spectrometer combined with a Perkin-Elmer Sigma 3 gas chromatograph, equipped with a Permabond OV-1, $0.25 \mu \mathrm{m}$, $25 \mathrm{~m} \times 0.32 \mathrm{~mm}$ ID capillary column (Macherey \& Nagel, Düren, Germany).

GC-conditions: The carrier gas was helium at $70 \mathrm{kPa}$ inlet pressure, the split-exit was set at $30 \mathrm{ml} / \mathrm{min}$, the injector temperature was $290^{\circ} \mathrm{C}$, the oven temperature was isothermal $270^{\circ} \mathrm{C}$, the transfer line was heated to $290^{\circ} \mathrm{C}$.

MS-conditions: El-Modus $(70 \mathrm{eV})$, selected mass detection at $\mathrm{m} / \mathbf{z}$ $=502 \pm 0.25$ (for $\alpha$-tocopherol) and $\mathrm{m} / \mathrm{z}=508 \pm 0.25$ (for $\alpha$ tocopherol- $\mathrm{d}_{6}$ ), 0.28 seconds per scan and 0.14 seconds scantime per mass.

\section{Procedures and measurements}

\section{Weighing procedures}

The standard substances were weighed on a microbalance (Mikrowaage 708501 , Sartorius, Göttingen, Germany). All other weighing procedures, including all required calibrations of volumetric devices, were done on a semimicrobalance (Halbmikrowaage 2004 MP, Sartorius, Göttingen, Germany).

\section{Preparation of the stock solutions of the standards and internal standards for the HPLC methods}

The stock standards were prepared to a concentration of $10 \mathrm{~g} / 1$ by dissolving $0.5 \mathrm{~g} D, L$ - $\alpha$-tocopherol or $D, L$ - $\alpha$-tocopherol acetate in $50 \mathrm{ml}$ ethanol. Following 1:10 dilution, $1 \mathrm{ml}$ aliquots of the standards containing $1 \mathrm{~g} / 1$ standard and internal standard were stored at $-20^{\circ} \mathrm{C}$. The internal standard for the HPLC method with fluorescence detection was prepared to a concentration of $1 \mathrm{~g} / \mathrm{l}$ by dissolving $0.1 \mathrm{~g}$ tocol in $100 \mathrm{ml}$ ethanol. This stock solution was directly aliquoted and stored at $-20^{\circ} \mathrm{C}$.

\section{Preparation of the standards for the HPLC method with $U V$-absorbance detection}

The $D, L-\alpha$-tocopherol acetate standard was diluted with ethanol before use to give a concentration of $150 \mathrm{mg} / \mathrm{l}$. For quantification three standards were prepared by mixing $500 \mu \mathrm{l}$ of the internal standard with $25 \mu \mathrm{l}, 75 \mu \mathrm{l}$ or $150 \mu \mathrm{l}$ of the $D, L-\alpha$-tocopherol standard and adding methanol to give a final volume of $5 \mathrm{ml}$. This result in three standards containing $5 \mathrm{mg} / 1 \mathrm{D}, L$ - $\alpha$-tocopherol/15 $\mathrm{mg} / 1 \quad D, L$ - $\alpha$-tocopherol acetate, $15 \mathrm{mg} / 1 \quad D, L$ - $\alpha$-tocopherol $/ 15 \mathrm{mg} / 1$ $D, L$ - $\alpha$-tocopherol acetate and $30 \mathrm{mg} / 1 D, L$ - $\alpha$-tocopherol $/ 15 \mathrm{mg} / 1$ $D, L-\alpha$-tocopherol acetate. These standards $(30 \mu \mathrm{l})$ were injected for HPLC analysis.

\section{Preparation of the serum samples for the HPLC method with} $U V$-absorbance detection

Serum $(500 \mu \mathrm{l})$ and $50 \mu \mathrm{l}$ internal standard $(7.5 \mu \mathrm{g} D, L$ - $\alpha$-tocopherol acetate) were pipetted into a glass tube and mixed thoroughly for $15 \mathrm{~s}$. After equilibrating for $10 \mathrm{~min} 500 \mu \mathrm{l}$ ethanol were added, mixed for $15 \mathrm{~s}$ and then $1 \mathrm{ml}$ hexane was added. The mixtures were then thoroughly mixed for $10 \mathrm{~min}$, followed by centrifugation $(10000 \mathrm{~g})$ for $5 \mathrm{~min}$ to enhance phase separation. The hexane phase $(900 \mu \mathrm{l})$ was evaporated to dryness under a nitrogen stream at $60^{\circ} \mathrm{C}$. The residue was reconstituted with $200 \mu$ lacetonitrile and $30 \mu \mathrm{l}$ were injected for HPLC analysis.

\section{Calibration and calculation}

The calculation was perfomed using Maxima 825 software and was based on the peak area ratios of the determined $D, L-\alpha$-tocopherol and the internal standard $D, L$ - $\alpha$-tocopherol acetate. A linear relationship was assumed between the concentration of the $D, L-\alpha$-tocopherol and the peak area ratio. The measuring range covered by the three standards was $5 \mathrm{mg} / 1$ to $30 \mathrm{mg} / 1 D, L$ - $\alpha$-tocopherol. For samples with a peak area ratio outside this range an extrapolation was performed.

\section{Preparation of the standards for the HPLC method with} fluorescence detection

The tocol standard was diluted with ethanol before use to give a concentration of $100 \mathrm{mg} / \mathrm{l}$. For quantification, three standards were prepared by mixing $500 \mu \mathrm{l}$ of the internal standard with $25 \mu \mathrm{l}, 50 \mu \mathrm{l}$ or $100 \mu \mathrm{l}$ of the $D, L$ - $\alpha$-tocopherol standard and adding methanol to give a final volume of $20 \mathrm{ml}$. This resulted in three standards containing $1.25 \mathrm{mg} / 1 \mathrm{D}, L$ - $\alpha$-tocopherol $/ 2.5 \mathrm{mg} / 1$ tocol, $2.5 \mathrm{mg} / \mathrm{l}$ $D, L$ - $\alpha$-tocopherol $/ 2.5 \mathrm{mg} / 1$ tocol and $5 \mathrm{mg} / 1 D, L$ - $\alpha$-tocopherol $/ 2.5$ $\mathrm{mg} / \mathrm{l}$ tocol by mixing appropriate amounts of standards and methanol. These mixtures $(50 \mu \mathrm{l})$ were injected for HPLC analysis.

\section{Preparation of serum samples for the HPLC method with} fluorescence detection

Serum $(250 \mu \mathrm{l})$ and $25 \mu \mathrm{l}$ internal standard $(2.5 \mu \mathrm{g}$ tocol $)$ were pipetted into a glass tube and mixed thoroughly for $15 \mathrm{~s}$. After equilibrating for $10 \mathrm{~min}, 500 \mu \mathrm{l}$ ethanol were added and, after mixing for $15 \mathrm{~s}, 1 \mathrm{ml}$ hexane. These mixtures were thoroughly mixed for $10 \mathrm{~min}$, followed by centrifugation $(10000 \mathrm{~g})$ for $5 \mathrm{~min}$ to enhance phase separation. The hexane phase $(900 \mu l)$ was evaporated to dryness under a nitrogen stream at $60^{\circ} \mathrm{C}$. The residue was reconstituted with $200 \mu \mathrm{l}$ acetonitrile and $50 \mu \mathrm{l}$ were injected for HPLC analysis.

\section{Calibration and calculation}

The calculation was performed using Maxima 825 software and was based on the ratio of the peak areas of the determined $D, L-\alpha-$ tocopherol and the internal standard tocol. A linear relationship was assumed between the concentration of the $D, L-\alpha$-tocopherol and the peak area ratio. The measuring range covered by the three standards was $5 \mathrm{mg} / 1$ to $20 \mathrm{mg} / 1 \quad D, L$ - $\alpha$-tocopherol. For samples with a peak area ratio outside this range an extrapolation was performed.

Preparation of the stock solutions of the standards and internal standards for the ID-GC-MS method

The stock standards were prepared by dissolving $10 \mathrm{mg} D, L-\alpha-$ tocopherol in $50 \mathrm{ml}$ ethanol. The internal standard for the ID-GCMS method was prepared by dissolving $5 \mathrm{mg} \alpha$-tocopherol- $\mathrm{d}_{6}$ in $25 \mathrm{ml}$ ethanol. Aliquots of these standards were stored at $-20^{\circ} \mathrm{C}$. 


\section{Preparation of the standards for the ID-GC-MS method}

The $D, L$ - $\alpha$-tocopherol standard was diluted $1: 16$ with ethanol before use to give a concentration of $12.5 \mathrm{mg} / \mathrm{l}$. For quantification three standards were prepared by mixing $25 \mu \mathrm{l}$ internal standard with $300 \mu \mathrm{l}, 400 \mu \mathrm{l}$ or $500 \mu \mathrm{l} D, L$ - $\alpha$-tocopherol standard, giving isotope ratios of $0.75,1.00$ and 1.25 . These mixtures, one sample containing $5 \mu \mathrm{g}$ pure standard and one sample containing $5 \mu \mathrm{g}$ pure internal standard were evaporated to dryness under a nitrogen stream at $60^{\circ} \mathrm{C}$. The residue was then reconstituted with $50 \mu \mathrm{l}$ TriSil Z-reagent (TMSI/pyridine) and incubated for $60 \mathrm{~min}$ at $65^{\circ} \mathrm{C}$. Then $1.5 \mu \mathrm{l}$ were injected for the GC-MS analysis.

\section{Preparation of the serum samples for the ID-GC-MS method}

Serum $(200$ to $500 \mu \mathrm{l})$ (corresopnding to an amount of about $5 \mu \mathrm{g}$ $D, L$ - $\alpha$-tocopherol) and $25 \mu \mathrm{l}$ internal standard containing $5 \mu \mathrm{g} \alpha$ tocopherol- $\mathrm{d}_{6}$ were pipetted into a glass tube, bidemin. water was added to give a volume of at least $500 \mu \mathrm{l}$. After equilibrating for $10 \mathrm{~min}, 500 \mu \mathrm{l}$ ethanol and $1 \mathrm{ml}$ hexane were added, mixed for 10 min and then centrifuged $(10000 \mathrm{~g})$ for $5 \mathrm{~min}$ to enhance phase separation. The hexane phase $(950 \mu \mathrm{l})$ evaporated to dryness under a nitrogen stream at $60^{\circ} \mathrm{C}$ and the residue was reconstituted with $1 \mathrm{ml}$ methanol. This solution was loaded onto Sep-Pak- $\mathrm{C}_{18}$ solidphase extraction columns and after washing to columns with $2 \mathrm{ml}$ bidemin. water and $2 \mathrm{ml}$ methanol/water ( $70 / 30 \mathrm{by}$ vol.), the analyte was eluted from the column with 5 times $1 \mathrm{ml}$ methanol, discarding the first portion of the eluent. The methanolic solution was evaporated to dryness under a nitrogen stream at $60^{\circ} \mathrm{C}$. Then the residue was reconstituted with $50 \mu \mathrm{l}$ TriSil Z-reagent (trimethylsilylimidazole/pyridine) and incubated for $60 \mathrm{~min}$ at $65^{\circ} \mathrm{C}$, and 1.5 $\mu$ l were injected for the GC-MS analysis.

\section{Calibration and calculation}

The peak integration was performed using Finnigan-1020 Software. Subsequent calculations were performed using the procedure described by Siekmann \& Breuer (4).
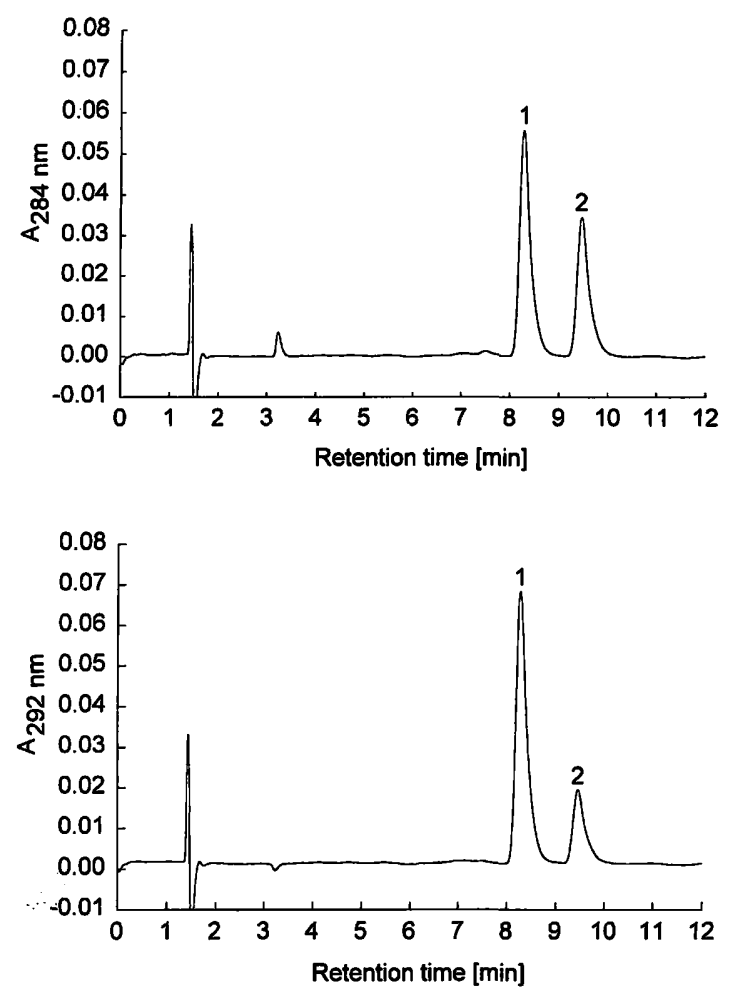

Fig. 1a Dual wavelength UV-chromatogram at $284 \mathrm{~nm}$ and 292 $\mathrm{nm}$ of a standard sample containing $15.0 \mathrm{mg} / \mathrm{l} \alpha$-tocopherol (peak 1) and $15.0 \mathrm{mg} / \mathrm{l} \alpha$-tocopherol acetate (peak 2) as internal standard.

\section{Results}

\section{HPLC method with UV-absorbance detection}

A sufficient separation for the $D, L-\alpha$-tocopherol and the $D, L$ - $\alpha$-tocopherol acetate is attained, as shown for a standard in figure 1a and a serum preparation in figure $1 \mathrm{~b}$. The ratio of the peak areas is as expected from the molar absorbance coefficient of $D, L$ - $\alpha$-tocopherol and $D, L$ - $\alpha$-tocopherol acetate at the wavelengths $\lambda=284$ $\mathrm{nm}$ and $\lambda=292 \mathrm{~nm}(5) . D, L-\alpha$-Tocopherol acetate has its absorbance maximum at $\lambda=284 \mathrm{~nm}$ and therefore we chose this wavelength to optimize the response of the internal standard. The second wavelength of $\lambda=292$ $\mathrm{nm}$ was only used for purity checking by calculating the absorbance ratio $292 \mathrm{~nm} / 284 \mathrm{~nm}$.

The within-run imprecision (tab. 1a) was below $2 \%$ for standards and below $2.5 \%$ for serum pools with concentrations between $3 \mathrm{mg} / \mathrm{l}$ and $30 \mathrm{mg} / \mathrm{l}$. The day-to-day imprecision, assessed for the same serum pools, was always below 5\% (tab. 2a). Standard addition experiments never showed a recovery significantly deviating from $100 \%$ (tab. 3).

\section{HPLC method with fluorescence detection}

A sufficient separation for the $D, L-\alpha$-tocopherol and the $D, L-\alpha$-tocol is attained at shorter retention times compared to the method using absorbance detection, as shown for a standard and a serum preparation in fig-
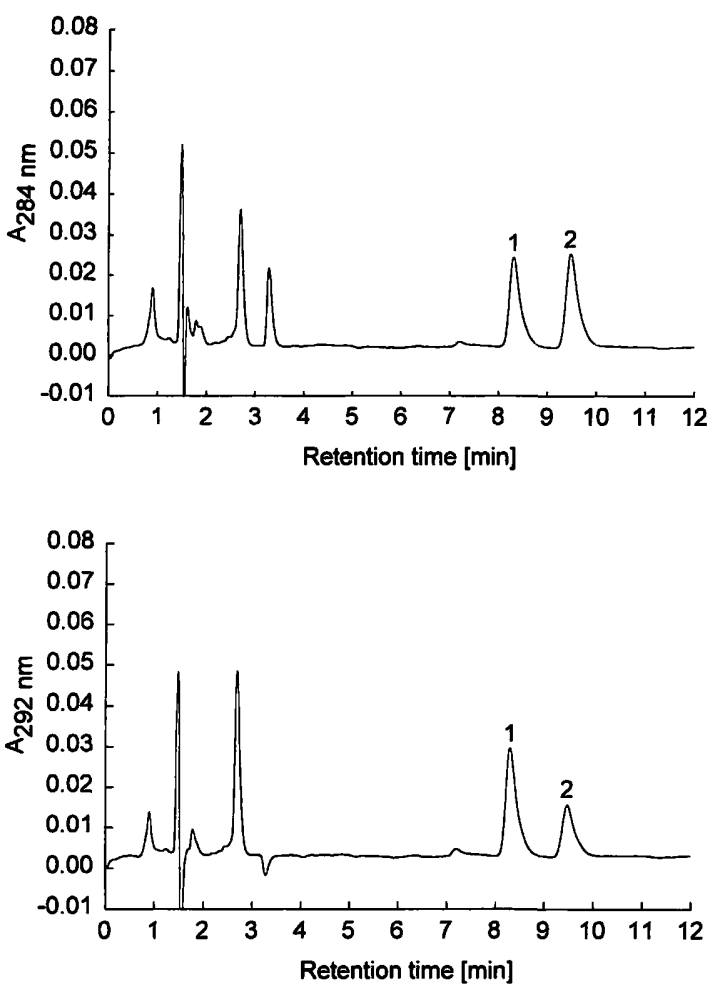

Fig. 1b Dual wavelength UV-chromatogram at $284 \mathrm{~nm}$ and 292 $\mathrm{nm}$ of a serum sample containing $9.2 \mathrm{mg} / \mathrm{l} \alpha$-tocopherol (peak 1) and $15.0 \mathrm{mg} / 1 \alpha$-tocopherol acetate (peak 2) as internal standard. 
ure 2, obtained with an excitation wavelength of $292 \mathrm{~nm}$ and an emission wavelength of $325 \mathrm{~nm}$. A complete chromatographic run takes 7-8 min compared to 10$11 \mathrm{~min}$ for the former method.

The within-run imprecision (tab. 1 b) was below $1 \%$ for standards as well as serum pools with concentrations between $3 \mathrm{mg} / 1$ and $30 \mathrm{mg} / 1$, and the day-to-day imprecision (tab. 2b), assessed for the same serum pool was always below $1.5 \%$. Standard addition experiments (tab. 3) never showed a recovery significantly deviating from $100 \%$.

\section{Isotope dilution-gas chromatography-mass spectrometry method}

Figures $3 a$ and $3 b$ show the mass spectra of the trimethylsilyl derivatives of $\alpha$-tocopherol and $\alpha$-toco-

Tab. 1 Within-run imprecision for the two HPLC methods for the determination of $\alpha$-tocopherol, calculated for three aqueous stan-

dards and four, respectively five, human pool sera from $n=10$ runs.

$\begin{array}{llllllll}\text { Standard } & \text { Standard } & \text { Standard } & \text { Poolserum } & \text { Poolserum } & \text { Poolserum } & \text { Poolserum } & \text { Poolserum } \\ 1 & 2 & 3 & 1 & 2 & 3 & 4 & 5\end{array}$

a) Determination of $\alpha$-tocopherol by HPLC combined with UV-detection

$\begin{array}{llcccccc}\text { Mean [mg/l] } & 4.9 & 14.8 & 30.8 & 3.2 & 8.9 & 14.4 & 28.9 \\ \text { SD [mg/l) } & 0.09 & 0.16 & 0.49 & 0.07 & 0.14 & 0.24 \\ \text { CV [\%] } & 1.9 & 1 & 1.6 & 2.2 & 1.6 & 1.7\end{array}$

b) Determination of $\alpha$-tocopherol by HPLC combined with fluorescence detection

\begin{tabular}{|c|c|c|c|c|c|c|c|c|}
\hline Mean [mg/l] & 5.0 & 10.0 & 21.1 & 2.7 & 5.6 & 11.9 & 18.6 & 23.6 \\
\hline $\mathrm{SD}[\mathrm{mg} / \mathrm{l}]$ & 0.04 & 0.03 & 0.10 & 0.02 & 0.02 & 0.03 & 0.09 & 0.14 \\
\hline $\mathrm{CV}[\%]$ & 0.7 & 0.3 & 0.5 & 0.9 & 0.4 & 0.3 & 0.5 & 0.6 \\
\hline
\end{tabular}

$\mathrm{CV}=$ coefficient of variation in $\%$

Tab. 2 Day to day imprecision for the three methods for the determination of $\alpha$-tocopherol, calculated for four, respectively five, human pool sera from $n=10$ runs.

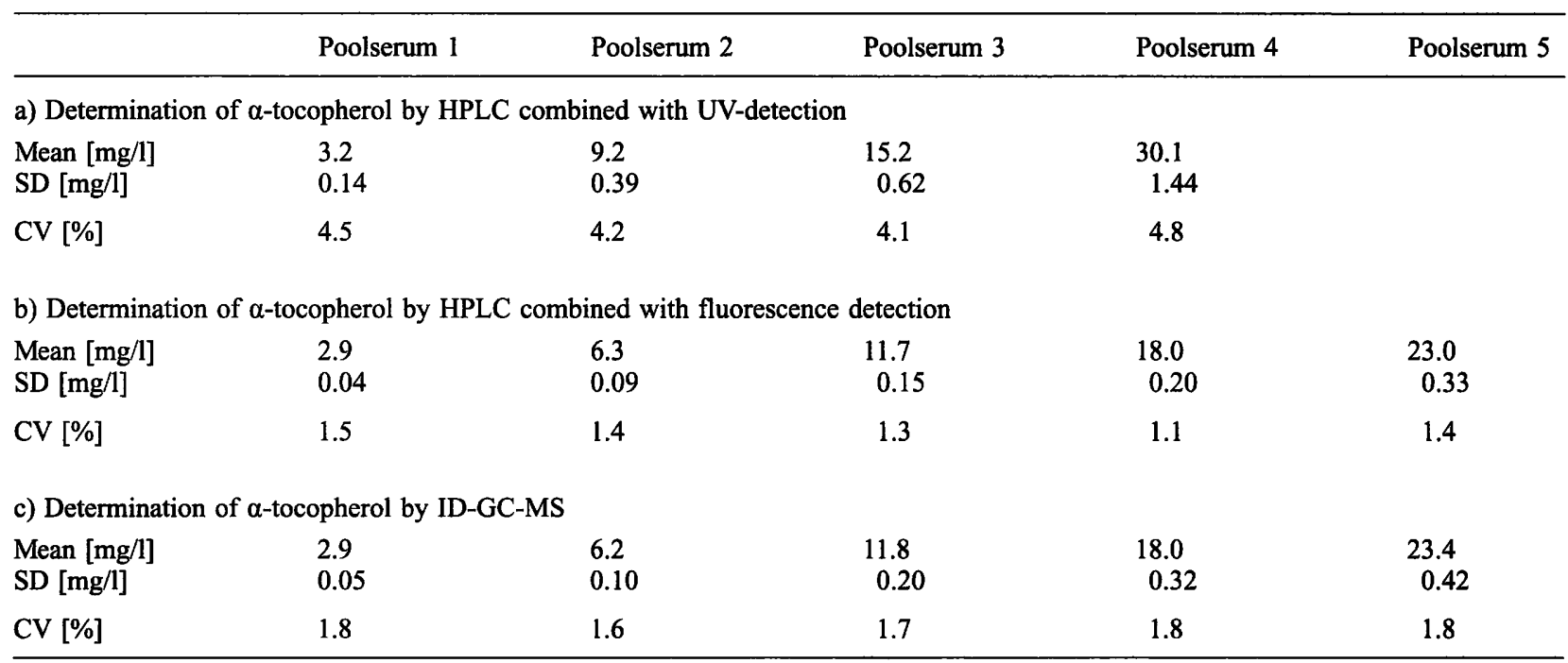

$\mathrm{CV}=$ coefficient of variation in $\%$

Tab. 3 Recovery of the three methods for the determination of $\alpha$-tocopherol, calculated for Pool 1, spiked with $\alpha$-tocopherol.

\begin{tabular}{|c|c|c|c|c|c|}
\hline \multicolumn{2}{|c|}{ HPLC/UV-detection } & \multicolumn{2}{|c|}{ HPLC/fluorescence-detection } & \multicolumn{2}{|l|}{ ID-GC-MS } \\
\hline $\begin{array}{l}\text { Addition of } \\
\alpha \text {-tocopherol } \\
{[\mathrm{mg} / 1]}\end{array}$ & $\begin{array}{l}\text { Recovery } \\
{[\%]}\end{array}$ & $\begin{array}{l}\text { Addition of } \\
\alpha \text {-tocopherol } \\
{[\mathrm{mg} / \mathrm{l}]}\end{array}$ & $\begin{array}{l}\text { Recovery } \\
{[\%]}\end{array}$ & $\begin{array}{l}\text { Addition of } \\
\alpha \text {-tocopherol } \\
\text { [mg/l] }\end{array}$ & $\begin{array}{l}\text { Recovery } \\
{[\%]}\end{array}$ \\
\hline 5.0 & $100.1 \pm 0.7$ & 5.0 & $100.4 \pm 0.7$ & 3.75 & $98.6 \pm 1.6$ \\
\hline 10.0 & $99.5 \pm 0.7$ & 10.0 & $100.2 \pm 0.8$ & 5.00 & $98.8 \pm 0.9$ \\
\hline 20.0 & $99.3 \pm 0.5$ & 20.0 & $99.8 \pm 0.6$ & 6.25 & $98.5 \pm 1.7$ \\
\hline 30.0 & $100.4 \pm 0.8$ & 30.0 & $100.6 \pm 0.7$ & - & - \\
\hline
\end{tabular}


pherol- $\mathrm{d}_{6}$. For quantification we used the mass $\mathrm{m} / \mathrm{z}$ $=502$ for $\alpha$-tocopherol and $\mathrm{m} / \mathrm{z}=508$ for $\alpha$-tocopherol- $d_{6}$. For all serum samples the selected ionmonitoring chromatograms looked like figure 4 and had no interfering peak.
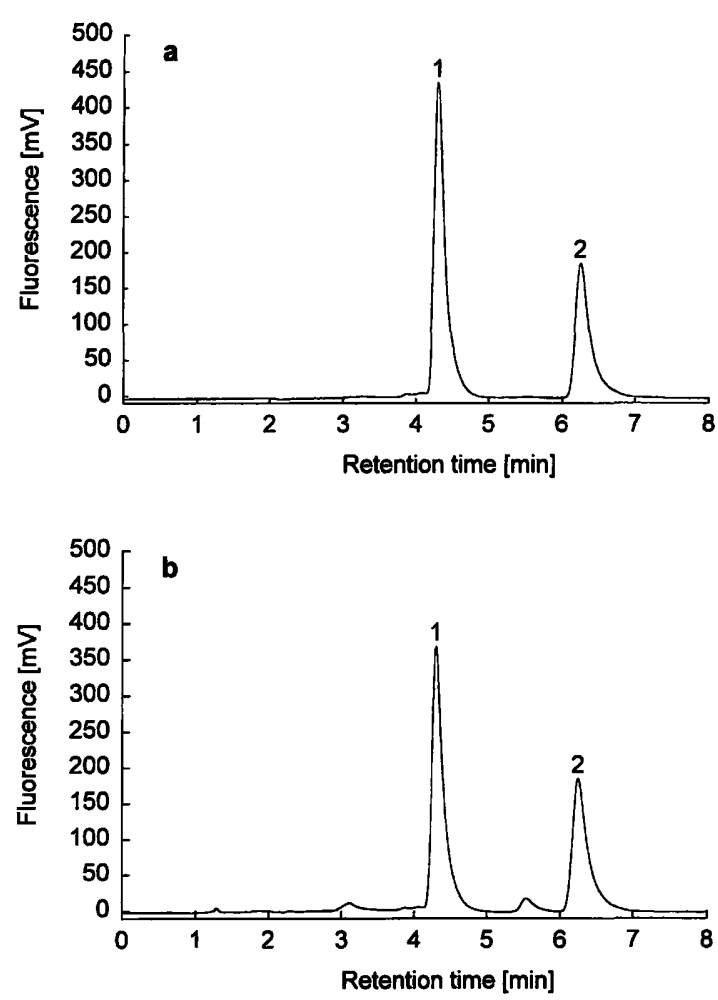

Fig. 2 Fluorescence chromatograms

a) of a standard sample containing $10.0 \mathrm{mg} / 1$ tocol as internal standard (peak 1) and $10.0 \mathrm{mg} / \mathrm{l} \alpha$-tocopherol (peak 2)

b) of a serum sample containing $10 \mathrm{mg} / \mathrm{l}$ tocol as internal standard (peak 1) and $11.7 \mathrm{mg} / 1 \alpha$-tocopherol (peak 2)
The day-to-day imprecision (tab. 2c) for serum pools with concentrations between $3 \mathrm{mg} / 1$ and $30 \mathrm{mg} / \mathrm{l}$ never exceeded $1.8 \%$ and the standard addition experiments (tab. 3), performed at a lower concentration range than used for the HPLC methods, showed a recovery of $100 \%$, deviating not more than 1.3 standard deviations.

\section{Method comparisons}

The results of the three methods were compared using the Passing-Bablok method (6) for $\mathrm{n}=25$ serum samples with $\alpha$-tocopherol concentrations between $5 \mathrm{mg} / \mathrm{l}$ and 25 $\mathrm{mg} / \mathrm{l}$ and the following relationships were obtained:

For the comparison of the ID-GC-MS method and the HPLC method with fluorimetric detection (fig. 5a)

$c_{\alpha-\text { tocopherol, HPLC-fluorescence }}$

$$
=1.027 \times c_{\alpha \text {-tocopherol, ID-GC-MS }}+0.085 \mathrm{mg} / \mathrm{l}
$$

confidence interval for slope $b: 0.998-1.057$

confidence interval for intercept a:

$-0.31 \mathrm{mg} / \mathrm{l}-+0.48 \mathrm{mg} / \mathrm{l}$

coefficient of correlation $\mathrm{r}: \quad 0.998$

For the comparison of the ID-GC-MS method and the HPLC method with absorbance detection (fig. $5 b$ )

$c_{\alpha \text {-tocopherol, HPLC-absorbance }}$

$$
=1.094 \times c_{\alpha \text {-tocopherol, ID-GC-MS }}+0.73 \mathrm{mg} / 1
$$

confidence interval for slope $b$ : $1.001-1.187$

confidence interval for intercept a:

$-0.53 \mathrm{mg} / \mathrm{l}-+1.98 \mathrm{mg} / \mathrm{l}$

coefficient of correlation r: $\quad 0.981$

For the comparison of the HPLC method with fluorimetric detection and the HPLC method with absorbance detection

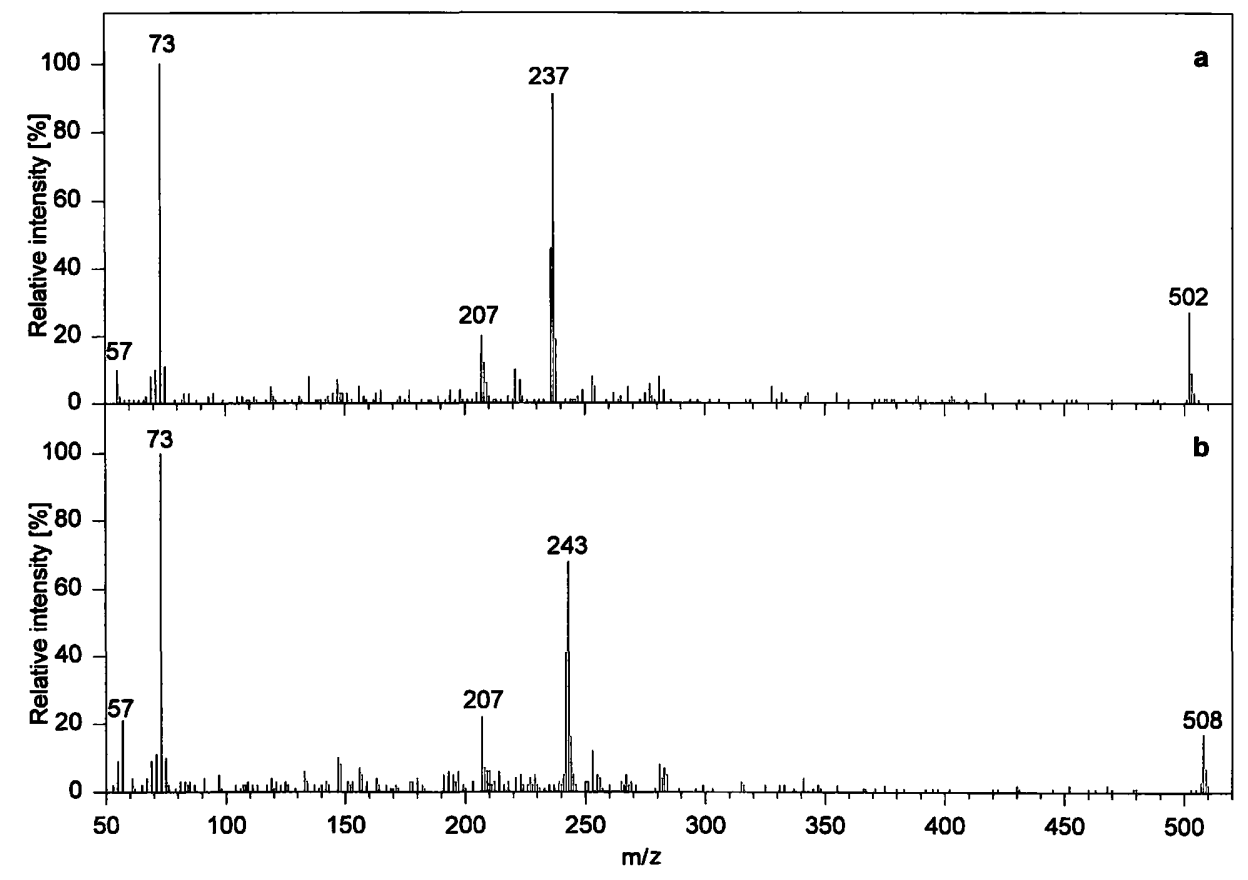

Fig. 3 a) Mass spectrum of the trimethylsilylated $\alpha$-tocopherol b) Mass spectrum of the trimethylsilylated $\alpha$-tocopherol- $\mathrm{d}_{6}$ 


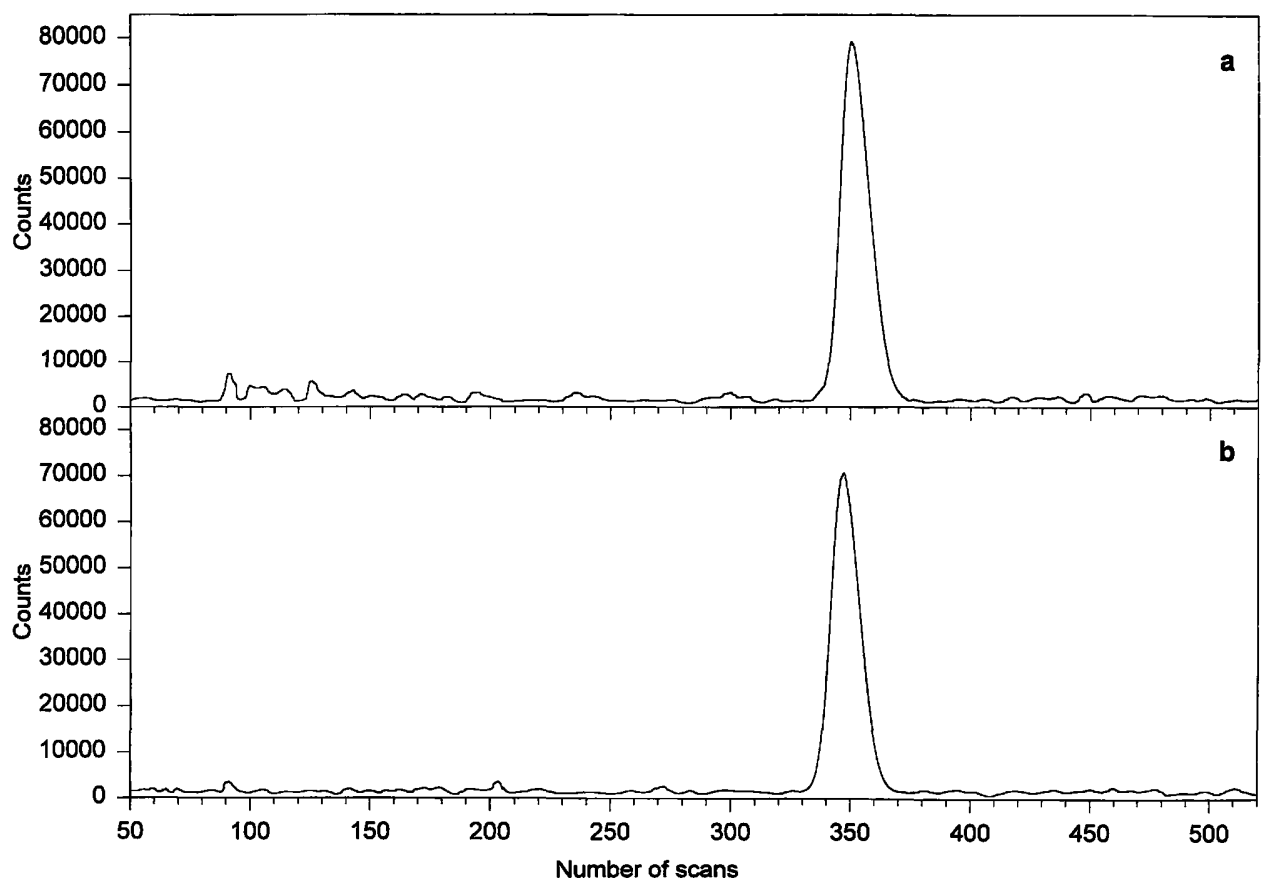

Fig. 4 Selected ion-monitoring chromatograms a) of $\alpha$-tocopherol at $\mathrm{m} / \mathrm{z}=502$ and $\mathrm{b}$ ) of $\alpha$-tocopherol- $\mathrm{d}_{6}$ at $\mathrm{m} / \mathrm{z}=508$ for a serum sample. The serum sample contained $13.5 \mathrm{mg} / \mathrm{l} \alpha$-tocopherol

$c_{\alpha \text {-tocopherol, HPLC-absorbance }}$

$=1.053 \times c_{\alpha \text {-tocopherol, HPLC-fluorescence }}+0.51 \mathrm{mg} / 1$

confidence interval for slope b: $0.968-1.138$

confidence interval for intercept a:

$-0.67 \mathrm{mg} / 1-+1.69 \mathrm{mg} / 1$

coefficient of correlation r: 0.983

The respective difference plots are shown in figs. $6 \mathrm{a}-\mathrm{c}$. The relative differences between the results obtained by the ID-GC-MS method and the HPLC method with fluorescence detection (fig. 6a) showed a bias with a mean of $3.5 \%$ and a standard deviation, indicating the scattering of the bias, of $3.0 \%$. The relative differences between the results obtained by the ID-GC-MS method and the HPLC method with and $500 \mu 1$ serum were used for sample preparation as described in methods and materials.

UV-detection (fig. 6b) had a mean of $14.3 \%$ and a standard deviation of $10.4 \%$. In the case of the comparison between the HPLC method with fluorescence detection and the HPLC method with UV-detection (fig. 6c), the mean was $10.4 \%$ and the standard deviation $9.2 \%$, the bias showed a significant concentration dependence.

\section{Reference range}

Table 4 summarizes the data for a tentative reference range determination for serum samples from $n=64$ male and $n=66$ female subjects using the HPLC method with fluorescence detection. No significant dependence of sex and age, except that the results for males below 10 years were lower, could be found. The
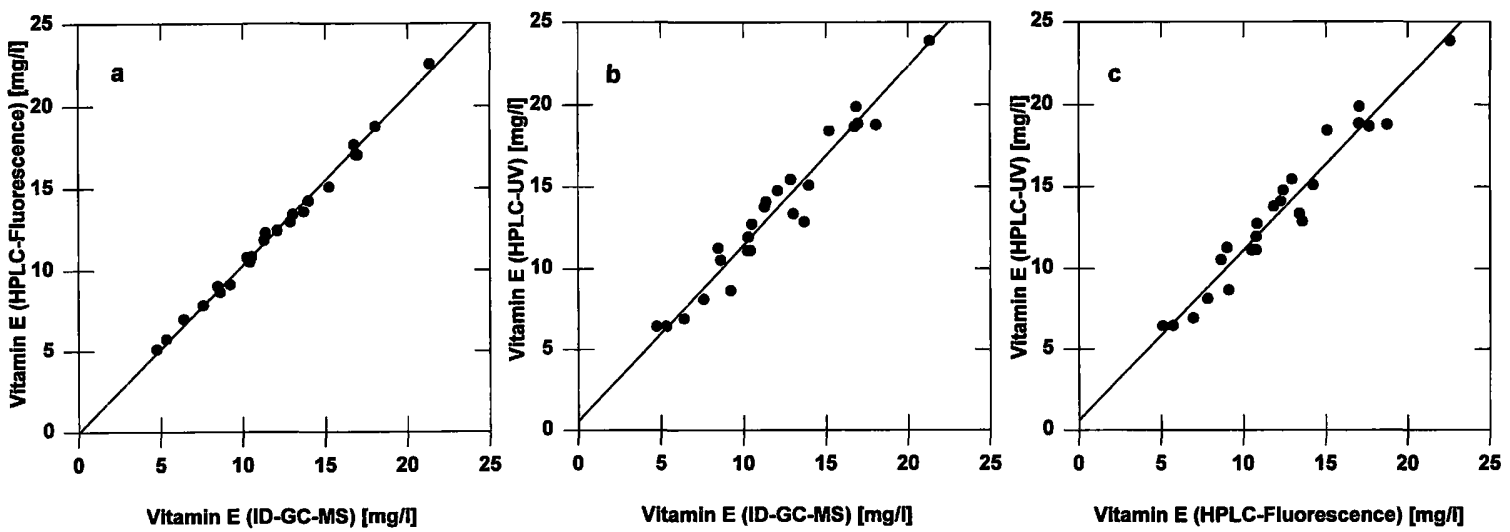

Fig. 5 Method comparison for $r=25$ samples for the three methods compared

a) Vitamin E (ID-GC-MS) vs. Vitamin E (HPLC-fluorescence)

b) Vitamin E (ID-GC-MS) vs. Vitamin E (HPLC-UV)

c) Vitamin E (HPLC-fluorescence) vs. Vitamin E (HPLC-UV) 

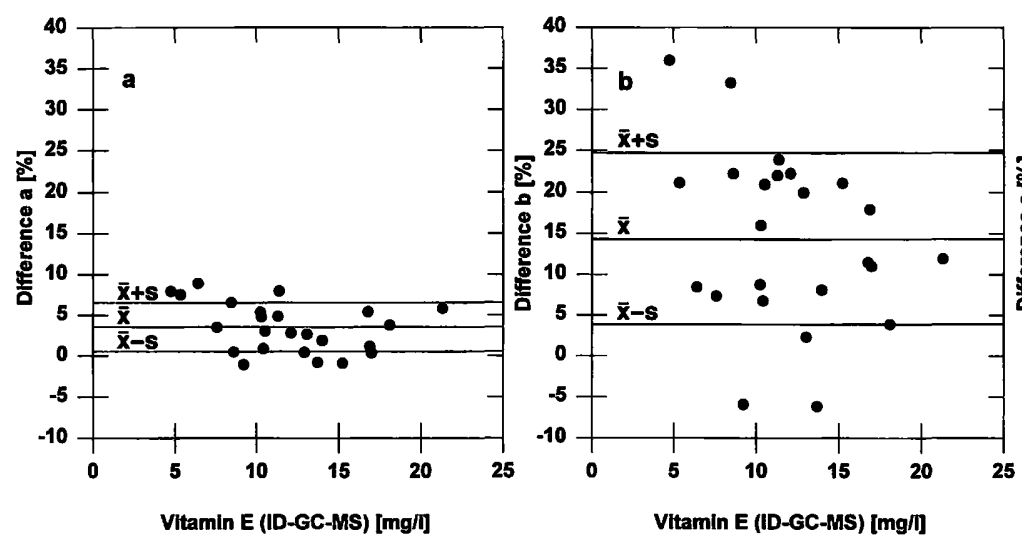

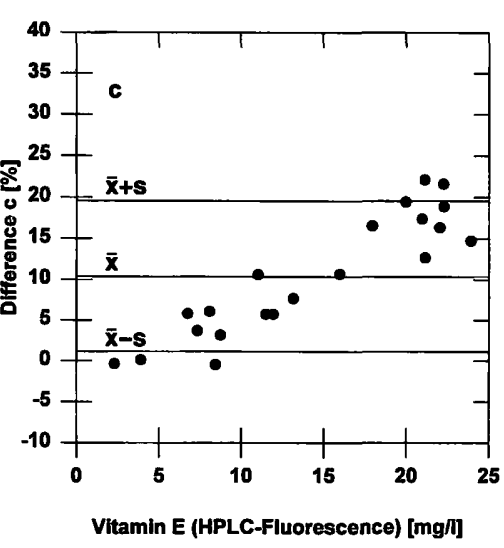

Fig. 6 Difference plots for $\mathrm{n}=25$ samples for the three methods compared, including the

a) Vitamin E (ID-GC-MS) vs. Difference a $=100 \times($ Vitamin $\mathrm{E}$ (HPLC-Fluorescence) - Vitamin E (ID-GC-MS))/Vitamin E (IDGC-MS)

Mean $\overline{\mathrm{x}}=3.5 \% \quad$ Standard deviation $\mathrm{s}=3.0 \%$

reference range from all $n=120$ samples from males and females with an age of 10 and more years is $(\overline{\mathrm{x}} \pm 3 \mathrm{~s})$ is $(3.2-21.8) \mathrm{mg} / \mathrm{l}$.

\section{Conclusions}

The aim of this study was the evaluation of two highperformance liquid chromatographic methods for the determination of $\alpha$-tocopherol with different detection methods compared to an isotope dilution-gas chromatography-mass spectrometry method as the reference method. Due to the fact that reference materials with certified reference values for the analyte of interest are not commercially available, this is the only way to access the inaccuracy of the methods under study.

Tab. 4 Reference range for $\alpha$-tocopherol in serum.

\begin{tabular}{lllll}
\hline Age [a] & $\mathrm{n}$ & \multicolumn{2}{l}{$\alpha$-Tocopherol $[\mathrm{mg} / \mathrm{l}]$} & \\
\cline { 3 - 5 } & Mean & $\begin{array}{l}\text { Standard } \\
\text { deviation }\end{array}$ & $\begin{array}{l}\text { Mini- } \\
\text { mum }\end{array}$ & $\begin{array}{l}\text { Maxi- } \\
\text { mum }\end{array}$
\end{tabular}

a) Males

$\begin{array}{crrrrr}-9 & 6 & 9.8 & 3.0 & 4.7 & 14.2 \\ 10-19 & 5 & 10.7 & 1.3 & 9.0 & 11.9 \\ 20-29 & 24 & 12.1 & 2.6 & 8.7 & 16.8 \\ 30-39 & 17 & 12.5 & 3.7 & 8.4 & 20.6 \\ 40-49 & 5 & 14.7 & 3.1 & 12.1 & 20.0 \\ >50 & 7 & 13.9 & 3.1 & 9.6 & 19.4 \\ \text { All males } & 64 & 12.3 & 3.1 & 4.7 & 20.6\end{array}$

b) Females

\begin{tabular}{crrrrr}
-9 & 4 & 12.0 & 1.2 & 10.3 & 12.9 \\
$10-19$ & 7 & 13.0 & 3.5 & 8.9 & 19.2 \\
$20-29$ & 27 & 12.7 & 2.6 & 8.5 & 18.1 \\
$30-39$ & 16 & 11.7 & 2.0 & 8.6 & 16.4 \\
$40-49$ & 6 & 13.4 & 2.6 & 10.7 & 18.4 \\
$>50$ & 6 & 13.6 & 3.3 & 10.3 & 19.2 \\
All females & 66 & 12.6 & 3.1 & 8.5 & 19.2 \\
\hline
\end{tabular}

b) Vitamin E (ID-GC-MS) vs. Difference $b=100 \times($ Vitamin $\mathrm{E}$ (HPLC-UV) - Vitamin E (ID-GC-MS))/Vitamin E (ID-GC-MS) Mean $\overline{\mathrm{x}}=14.3 \% \quad$ Standard deviation $\mathrm{s}=10.4 \%$

c) Vitamin E (HPLC-Fluorescence) vs. Difference c $=100 \times(\mathrm{Vi}-$ tamin E (HPLC-UV) - Vitamin E (HPLC-Fluorescence))/Vitamin E (HPLC-Fluorescence)

Mean $\overline{\mathrm{x}}=10.4 \% \quad$ Standard deviation $\mathrm{s}=9.2 \%$

The imprecision within-run was for all samples tested lower than $2.5 \%$ for the HPLC method with absorbance detection and lower than $1 \%$ for the HPLC method with fluorescence detection. The HPLC method with absorbance detection had a between-day imprecision lower than $5 \%$ for all serum pools, the HPLC method with fluorescence detection, as well as the ID-GC-MS, had a between-day imprecision lower than $2 \%$ with always a slightly better performance of the HPLC method.

The recovery experiments showed unexpectedly the worst imprecision for the ID-GC-MS method and a slight bias for this method. The method comparison showed a nearly perfect correlation for the results of the ID-GC-MS and the HPLC fluorescence method with a coefficient of correlation $r=0.998$. The HPLC absorbance method showed an inferior correlation with both other methods and this method led to slightly higher results than the other methods.

Unexpected in this study was the slighty inferior imprecision of the chosen ID-GC-MS reference method compared to the HPLC method with fluorescence detection. This may be due to the relative poor signal/noise ratio of the mass detection in the mass range used, and also dependent on the mass spectrometer used, although this is not an explanation for the slight bias observed in the recovery experiments, which remains unclear. Nevertheless, it could be shown that the combination of a suitable sample preparation with a liquid chromatography and a specific detection may lead to an analytical performance comparable to the isotope dilution principle (7).

Several biological functions have been found for $\alpha$-tocopherol, the most important are the function as antioxidant, its influence on the metabolism of arachidonic acid and the fluidity of membranes. Deficiency leads to en- 
hanced lipid-peroxidation and the neuromuscular system is affected first $(1,2,8-9)$. There is evidence that the function as radical scavenger is associated with an anticarcinogenetic effect. Due to these facts there is increasing interest in the monitoring of the concentration of $\alpha$-tocopherol. For wider clinical use reliable analytical methods and reference materials for standardization as well as quality control have to be established. Several methods for the determination of $\alpha$-tocopherol by HPLC have been described $(10-16)$. This study is the first where the reliability of the new methods was evaluated by method comparison of the results to those of an IDGC-MS method. The lack of internationally accepted standards and control materials prevented an assessment of the inaccuracy of the methods presented.

\section{References}

1. Bayer W, Schmidt K. Vitamine in Prevention und Therapie. Stuttgart: Hippokrates Verlag, 1991.

2. Burton GW, Traber MG. Vitamin E. Antioxidant activity, biokinetics, and bioavailability. Annu Rev Nutr 1990; 10:357-82.

3. Schmidt K, Bayer W, Blankenhorn G. Vitamin E - aktueller wissenschaftlicher Erkenntnisstand. Vita Min Spur 1990; 5:48-60.

4. Siekmann L, Breuer H. Determination of cortisol in human plasma by isotope dilution-mass spectrometry. J Clin Chem Clin Biochem 1982; 20:883-92.

5. Fasman GD. Handbook of chemistry and molecular biology. 3rd ed., part D, vol. II. Boca Raton, Florida. CRC Press 1976:153-5.

6. Passing H, Bablok W. A new biometrical procedure for testing the equality of measurements from different analytical methods. J Clin Chem Clin Biochem 1983; 21:709-20.

7. Kock R, Delvoux B, Tillmans U, Greiling H. A candidate reference method for the determination of uric acid in serum based on high performance liquid chromatography with an isotope dilution-gas chromatography-mass spectrometer method. J Clin Chem Clin Biochem 1989; 27:157-62.

8. Bieri JG, McKenna MC. Expressing dietary values for fat-soluble vitamins: changes in concepts and terminology. Am J Clin Nutr 1981; 34:289-95.

9. Sokol RJ. Vitamin E deficiency and neurologic disease. Ann Rev Nutr 1988; 8:351-73.

10. Bieri JG, Tolliver TJ, Catignani GL. Simultaneous determination of $\alpha$-tocopherol and retinol in plasma or red cells by high pressure liquid chromatography. Am J Clin Nutr 1979; $32: 2143-9$.
Both HPLC methods presented here have been evaluated as precise and accurate enough to be used for clinical use and the HPLC method with fluorescence detection has a comparable analytical performance to the IDGC-MS method used as reference method. The specificity of the fluorescence detection moreover allows the use of a different solvent for the liquid chromatography. This results in the reduction of the runtime for an analysis to 7-8 min compared to $10-11$ min required for one analysis using the absorbance detection. The range of applicability is not limited to serum or plasma, indeed the method may be applied to other biological materials, where the liquid-liquid extraction as sample preparation is sufficient for isolating the $\alpha$-tocopherol.

11. Catignani GL. An HPLC method for the simultaneous determination of retinol and $\alpha$-tocopherol in plasma or serum. Methods Enzymol 1986; 123:215-9.

12. Celardo A, Bortolotti A. Measurement of vitamin E in premature infants by reversed-phase high-performance liquid chromatography. J Chromatogr 1989; 490:432-8.

13. De Leenheer AP. Determination of serum $\alpha$-tocopherol (vitamin E) by high-performance liquid chromatography. Clin Chem 1978; 24:585-90.

14. De Leenheer AP, De Bevere VORC, De Ruyter MGM, Claeys AE. Simultaneous determinations of retinol and $\alpha$-tocopherol in human serum by high-performance liquid chromatography. J Chromatogr 1979; 162:408-13.

15. Kaplan LA, Miller JA, Stein EA, Stampfer MJ. Simultaneous high-performance liquid chromatographic analysis of retinol, tocopherols, lycopene and $\alpha$ - and $\beta$-carotene in serum and plasma. Methods Enzymol 1990; 189:155-67.

16. MacCrehan WA, Schönberger E. Determination of retinol, $\alpha-$ tocopherol, and $\beta$-carotene in serum by liquid chromatography with absorbance and electrochemical detection. Clin Chem 1987; 33:1585-92.

\section{Received November 4, 1996/March 3, 1997}

Corresponding author: Dipl.-Chem. Dr. med. Rüdiger Kock, Institut für Klinische Chemie und Pathobiochemie,

Universitätsklinikum der RWTH Aachen, Pauwelsstraße 30, D-52057 Aachen, Germany 